\title{
Manifestação Cultural Popular de Movimento Social e Interação Turística em Jaguarão/RS: Extinto São-João
}

\author{
Manifestación Cultural Popular de Movimiento Social y Interación \\ Turística en Yaguarón RS: Extinto São-João \\ Rodrigo Lages Lakman ${ }^{1}$ \\ 1 leiga1.rll@gmail.com, Universidade Federal do Pampa.
}

\begin{abstract}
Resumo
O presente artigo é resultado de uma roda de conversa sobre a extinção de eventos no município de Jaguarão/RS, que teve como objeto de pesquisa o evento de São João. Esta pesquisa se justifica por apresentar um fragmento da memória da população da cidade, o enfoque no valor da manifestação folclórica cultural, a relação da população com o evento junino e estes com o turismo. Nossa metodologia foi de entrevistas com setores público, privado e sociedade, buscou-se analisar os impactos dessa extinção e as perspectivas dessa possível reativação e seus reflexos como fator indispensável no planejamento turístico. Como resultado desta pesquisa, foi observado, a falta de diálogo entre os principais órgãos públicos e a necessidade de buscar parcerias com a iniciativa privada. Contudo, foi possível mobilizar e sensibilizar os envolvidos por meio de uma análise da situação atual e projeção futura, identificando as principais necessidades da continuidade do festejo de são João e desenvolvimento turístico no Município a partir do mesmo.
\end{abstract}

Palavras-Chave: extinção, interação turística, Jaguarão, manifestação cultural, são João.

\section{Introdução}

A busca por novas experiências e o desejo de conhecer outros povos e lugares com a intenção de satisfazer as curiosidades, faz com que as pessoas viagem, buscando atividades diferentes de seu cotidiano. Os festejos populares como manifestação cultural envolvendo o turismo, representam um grande papel na organização social e no desenvolvimento local, trazendo e gerando fluxo de renda, além de manter a população em frequente interação sócio cultural. Um evento como de são João em Jaguarão poderia ser aproveitado como potencial turístico, uma vez que os grandes projetos de desenvolvimento turístico aliados a ações culturais, trazem novas perspectivas as localidades receptoras.

O festejo de São João é festa popular de celebração folclórica do santo de mesmo nome, esta é a principal festa do mês de junho. O evento comumente traz a reunião dos moradores da localidade em um determinado ponto, em torno da fogueira para celebrar a noite do santo, que envolve a personificação e a representação de suas crenças. As principais características destas festas são as atrações simples, que envolve vários rituais culturais como o do casamento da roça, ato lúdico artístico.

Atualmente, se vê que os festejos populares estão caindo no esquecimento, um dos motivos é a disputa das tecnologias no espaço com a convivência em sociedade, os festejos tinham mais importância enquanto ferramenta de convivência comunitária, e demonstração do valor e a cultura de cada povo. A extinção do são Joao de Jaguarão teve como senário a descontinuidade da atuação dos governos, aliado a um desestimulo e uma não apropriação da comunidade em relação ao festejo. Porém, a presente pesquisa não tratou dos motivos da extinção do evento, e sim dos impactos sócios culturais reproduzidos pela ausência da festa. ( voltar na introdução ) ver autores nos comentários. 


\section{Objetivos}

Analisar os impactos que a extinção do evento São João gerou na esfera sócio cultural , e projeção do evento no setor turístico.

\section{Objetivos específicos}

Investigar as características do evento em Jaguarão.

Levantamento de dados referentes ao reflexo da extinção do festejo de são João na localidade.

Enfatizar as perspectivas da possível reativação do festejo na cidade, para a economia e o turismo no município.

\section{Metodologia}

A metodologia aplicada foi de natureza qualitativa e foi desenvolvida por meio de entrevistas em três perfis de questionários direcionados profissionais da área de educação oito questões, a população da localidade oito questões e aos agentes políticos nove questões. Dos entrevistados nas áreas educacional, econômicas e políticas buscou-se suas ressalvas positivas, negativas e os pontos de conflitos nos setores sociais e organizacionais do festejo. Buscamos identificar os principais aspectos sociais e culturais que o evento tem para a comunidade, o valor desta ação para a cultura local, e o valor íntimo de cada um relacionado ao festejo. Aproveitamos para instigar a visão turística dos entrevistados sobre eventos, para assim poder auxiliar futuramente a criação de novas ações, metas, estratégias e novas pesquisas na área. A procura pelo tema fez despertar a visão para o movimento turístico ligado aos eventos, e ao possível vetor de desenvolvimento e promoção da cidade.

\section{Resultados}

A pesquisa demonstrou a insatisfação dos munícipes com a extinção do evento de são João na localidade, esse festejo remontava uma atmosfera anual de convívio e interação social. Assim a falta de diálogo entre os governos e população, como uma certa inclinação dos agentes dos poderes locais em reestabelecer o são João como atividade no município. Foi evidenciado a importância para os moradores, visto que o festejo já vivido por um determinado período, hoje faz parte do saudosismo da localidade. A análise deste conjunto de informações, não indicou o surgimento de sentimento de apropriação mas colocou o festejo em uma nova ótica a ser explorada dentro do campo turístico. Refletiu a visão micro que toda a parte envolvida na entrevista tem do evento, do turismo e dos potenciais turísticos do município. Também apontou a fator pedagógico disciplinar existente em conjunto com o festejo, reforçando a interatividade social. O proposito foi atingido satisfatoriamente quando se detectou os impactos íntimos gerado na localidade e na sociedade com a extinção da comemoração da noite de são João.

\section{Referências}

COUTO, Carlos Henrique da Mota. Turismo de eventos. Universidade federal de santa Catarina. Campus Florianópolis. Teses e dissertações. Programa de pós-graduação em engenharia de produção-2004 
NÓBREGA, zulmira. A festa do maior são João do mundo: dimensões culturais da festa junina na cidade de campina grande. Tese (doutorado). Universidade federal da Bahia, faculdade de comunicação. Salvador. Repositório institucional UFBA -2013

MORAES, deborah, BARBOSA, luiz Gustavo, MARTELOTTE, marcela Cohen.Os impactos econômicos do turismo no município do rio de janeiro e suas implicações no desenvolvimento local. Observatório de Inovação do Turismo. UFRJ. Revista Acadêmica Volume 1 Número 2 $-2006$

DIAS, anderson felisberto. Cultura popular como atrativo turístico e práticas organizativas de grupos folclóricos. Universidade federal de santa Catarina. Campus Florianópolis. Teses e dissertações. Programa de pós-graduação em administração - 2007

ALDO, gomes leandro. O turismo em João pessoa e a construção da imagem da cidade. Universidade federal da Paraíba. Dissertação (Mestrado). UFPB/CCEN - 2006

FERREIRA, maria nazareth. Comunicação, resistência e cidadania: as festas populares. As Festas Populares na Expansão do Turismo: A Experiência Italiana, 2a Edição, revista e ampliada. São Paulo Arte\&Ciência -2005

FARIAS, edson. Economia e cultura no circuito das festas populares brasileiras. Universidade federal da Bahia. Programa de Pós-Graduação em Ciências Sociais. Sociedade e Estado.

Brasília. V. 20 -2006

BEZZI, meri Lourdes, NETO, helena brum. Regiões culturais: a construção de identidades e culturas no Rio Grande Do sul e sua manifestação na paisagem gaucha. UFSM. Dissertação de Mestrado defendida junto ao Programa de Pós-Graduação em Geografia -2008 